UDC 378.147:80

DOI https://doi.org/10.31470/2415-3729-2020-12-9-23

\title{
Philology Training at the University in the Light of the Systematic Approach
}

\section{Bosa Vita}

Doctor of Philosophy in Pedagogy (Ph.D), Associate Professor, Chair of Romance Philology and Comparative-typological Linguistics, Institute of Philology, Borys Grinchenko Kyiv University $\triangle$ 18/2 Bulvarno-Kudriavska Str, Kyiv, Ukraine, 04053 E-mail: v.bosa@kubg.edu.ua; vitta.fabian2000@gmail.com ORCID: http://orcid.org/0000-0001-7509-7044 ResearcheriD: https://publons.com/researcher/4059730//

Date of receipt of the article: September 28, 2020 Article accepted for publication: November 22, 2020

\section{Професійна підготовка філологів в університеті в світлі системного підходу}

\section{Віта Петрівна Боса}

кандидат педагогічних наук, доцент, доцент кафедри романської філології та порівняльно-типологічного мовознавства, Київського університету імені Бориса Грінченка $\bowtie$ вул. Бульварно-Кудрявська, 18/2, м.Київ, Україна, 04053

Дата надходження статті: 28 вересня 2020 р. Стаття прийнята до друку: 22 листопада 2020 р.

\section{Abstract}

The article describes the peculiarities of applying a systematic approach to the training of future philologists in universities. 
The research goal is to clarify the methodological features of a systematic approach to the philologist training in a modern university. The research methods are the scientific analysis, systematization, classification, modeling.

Results. The main factors determining the need for a systematic approach have been identified (the common sociocultural processes in the language environment of many countries lead to linguistic unification (formerly Englishspeaking) and to preservation of their linguistic identity as the basis for national identity; the increase of the level of individual mobility, in the field of education including, development of polylingual, bilingual and multicultural links in education; new challenges and risks in the area of professional training related to the digitalization and dissemination of online education models in the context of global pandemics and the distance education segment expansion). Moreover, basing on the analysis of scientific sources (methodological bases for the training of philologists; contents and basic models of the training of these specialists; ICT as a systematic resource for the training of philologists), the opinion about the necessity of application of pedagogical systemology to the professional training of studentsphilologists in university conditions is substantiated. The analysis of the pedagogical and linguistic segments of systemology made it possible to identify the leading systemic characteristics of the training of philologists at the university (essence, composition, structure, functions, history of the system) and to investigate the manifestation of the systemic characteristics of the studied phenomenon in the conditions of the university environment as a systemic object. It is noted that the training of future philologists at the university as a system is synergistic; the professional training of philologists at the university as a system object is characterized as a complex open dynamic purposeful system with characteristics of continuous self-organization.

Conclusions. It was concluded that the training of philologists as a complex system involves a certain number of 
structural components (content, human resources, information, technological resources) for its functioning; the system is openended (to other pedagogical systems) in its nature, complementarity and interconnection with the scientific and technological systems implemented in other areas of training. It has been proved that the systematic characteristics of the training of specialists in the field of philology are provided by the specific guidelines for the establishment, operation and development of this system; the objectives of the above-mentioned specialists' training determine its content and end result, that is a competent specialist in his or her professional field and qualified in the professional activity, capable of self-education and selfdevelopment.

Keywords: pedagogical systemology, linguistics, competence, synergetics.

\section{References}

1. Barbash, I. (2014). Formuvannia profesiinoi movnoliteraturnoi kompetentnosti maibutnikh uchyteliv-filolohiv yak pedahohichna problema.Problemy pidhotovky suchasnoho vchytelia [Formation of professional linguistic and literary competence of future teachers-philologists as a pedagogical problem. Uman: Problems of preparation of the modern teacher], 10 (P1), 152-157 [in Ukrainian].

2. Bakhtyn, M.M. (1997). Problemy teksta v lynhvystyke, fylolohyy y druhykh humanytarnblkh naukakh. Opyt fylosofskoho analyza.Russkaia slovesnost. Ot teoryy slovesnosty $k$ strukture teksta: Antolohya [Problems of the text in linguistics, philology and other humanities. The experience of philosophical analysis. Russian literature. From Literary Theory to Text Structure: Anthology]. Moscow: Academia [in Russian].

3. Bekh, Yu.V. \& Slieptsov, A.I. (2012). Filosofski problemy suchasnoho upravlinnia skladnymy systemamy: idei, pryntsypy $i$ modeli [Philosophical problems of modern management of complex systems: ideas, principles and models]. Kyiv: NPU im P. Drahomanov [in Ukrainian]. 
4. Bihych, O.B. (2004). Metodychna osvita maibutnoho vchytelia inozemnoi movy pochatkovoi shkoly [Methodical education of the future teacher of a foreign language of elementary school]. Kyiv: KNLU [in Ukrainian].

5. Blauberh, Y.V.\& Yudyn, E.H. (1973). Stanovlenye $y$ sushchnost systemnoho podkhoda [Formation and essence of the system approach]. Moscow: Nauka [in Russian].

6. Vozniuk, O.V.\& Dubaseniuk, O.A. (2009). Tsilovi oriientyry rozvytku osobystosti u systemi osvity: intehratyvnyi pidkhid [Targets of personality development in the education system: an integrative approach]. Zhytomyr: ZhDU im I. Franka [in Ukrainian].

7. Zinukova, N.V. (2009). Profesiino-metodychna pidhotovka studentiv-filolohiv u vyshchomu navchalnomu zakladi [Professional and methodical training of students-philologists in higher educational institution]. Dnipro: DUEP [in Ukrainian].

8. Ikonnikova, M. (2016). Metodolohichni oriientyry profesiinoi pidhotovky filolohiv [Methodological guidelines for professional training of philologists]. Khmelnytskyi: Pedagogical Discourse 21, 46-52 [in Ukrainian].

9. Koval, V.O. (2013). Teoretychni $i$ metodychni zasady formuvannia profesiinoi kompetentnosti maibutnikh uchytelivfilolohiv u vyshchykh pedahohichnykh navchalnykh zakladakh [Theoretical and methodical bases of formation of professional competence of future teachers-philologists in higher pedagogical educational institutions]. Uman [in Ukrainian].

10. Kononiuk, A.E. (2014). Systemolohyia. Obshchaia teoryia system [Systemology. General systems theory] Kyiv: Education of Ukraine [in Russian].

11. Semenoh, O.M. (2005). Profesiina pidhotovka maibutnikh uchyteliv ukrainskoi movy i literatury [Professional training of future teachers of Ukrainian language and literature]. Sumy: VVP «Mriia-1» TOV [in Ukrainian].

12. Chornei, N.B. \& Chornei R.K. (2005). Teoriia system $i$ systemnyi analiz [Systems theory and systems analysis]. Kyiv: MAUP [in Ukrainian]. 
13. Cummings, J. \& Janicki, T.N. (2020). What Skills Do Students Need? A Multi-Year Study of IT/IS Knowledge and Skills in Demand by Employers. USA Journal of Information Systems Education 31(3), 208-217.

14. Gajewska, E. \& Sowa, M. (2015). Sposoby ksztatcenia nauczycieli języków specjalistycznych: od rzeczywistości edukacyjnej do rozwiazań systemowych. Neofilolog, 44/2, 233-248.

15. Krajka, J. (2012). The Language Teacher in the Digital Age. Towards a Systematic Approach to Digital Teacher Development. Lublin: KUL.

16. Scialdone, M.J. \& Connolly, A.J. (2020). Teaching Tip: How to Teach Information Systems Students to Design Better User Interfaces through Paper Prototyping. USA: Journal of Information Systems Education, 31(3), 179-186.

17. Yong, J.A. (2020). Teaching Tip. The Development of a Red Teaming Service-Learning Course. USA: Journal of Information Systems Education (JISE), 31(3), 157-178.

\section{Вступ}

Професійна підготовка філолога як предмет дослідження в педагогічній науці детермінується нині кількома основними суспільними факторами різного рівня, серед яких: загальні соціокультурні процеси в мовному середовищі багатьох країн, що приводять, з одного боку, до мовної уніфікації (передовсім, англомовної), з іншого - до прагнення зберігати свою мовну ідентичність як запоруку ідентичності національної; зростання рівня індивідуальної мобільності, в тому числі й у освітній сфері; розвиток полілінгвальних, білінгвальних та мультикультурних зв 'язків у сфері освіти; нові виклики та ризики у галузі професійної підготовки фахівців, пов 'язані 3 діджиталізацією та поширенням он-лайнових моделей навчання в умовах глобальних пандемій та розширення дистанційного сегменту освіти. Внаслідок розвитку названих процесів зростає й 
рівень вимог до професійної кваліфікації та набору професійних компетенцій випускників філологічних факультетів, фахівців як у галузі рідної, так і іноземних мов. Означені вимоги, в свою чергу, тісно пов 'язані з сучасними методологічними концепціями, моделями, алгоритмами, принципами, підходами до професійної підготовки філологів.

Методологічні засади підготовки фахівців в умовах сучасного університету представлено у науковому доробку М. Бахтіна (Бахтін, 1997), О. Вознюка, О. Дубасенюк (Вознюк\&Дубасенюк, 2009), М. Іконнікової (Іконнікова, 2016), Дж. Камінга та Т. Яніцкого (Cummings\&Janicki, 2020), Й. Крайки (Krajka, 2012), $\quad$ Е. Гаєвської, М. Сови (Gajewska\&Sowa, 2015) та ін. Зміст та основні моделі підготовки філологів у ЗВО розробляються І. Барбаш (Барбаш, 2014), О. Бігич (Бігич, 2004), Н. Зінуковою (Зінукова, 2009), В. Коваль (Коваль, 2013), О. Семеног (Семеног, 2005) та ін. В останне десятиліття особливої актуальності набувають наукові дослідження в сфері використання ІКТ як потужного засобу та методологічного орієнтиру професійної підготовки фахівців-філологів (Дж. Йонг (Yong, 2020), М. Скальдоне, А. Конноллі (Scialdone\&Connolly, 2020), що суттєвим чином впливає на загальну методологічну картину означеної проблеми.

Водночас маємо констатувати, що визначені нами чинники, які детермінують зміни в науково-теоретичному аналізі проблеми професійної підготовки філологів в університеті, попри їх суттєвий вплив на системні характеристики реалізації освітніх програм за напрямом підготовки 035 «Філологія», у наукових публікаціях розкриті фрагментарно. Крім того, системний характер цих освітніх програм потребує більш глибокого осмислення, оскільки дедалі більше визначається інформаційно-технологічним ресурсом фахової підготовки філологів, наявним в університетах України, рівнем IКТ, розвитком імерсивних методів навчання тощо. 
У зв язку 3 цим метою статmі є з`ясування методологічних особливостей системного підходу до професійної підготовки філологів в умовах сучасного університету.

\section{Матеріал і методи досліджень}

Дослідження системного підходу в професійній підготовці майбутніх філологів грунтується на сучасній системології, загальній теорії систем із застосуванням методів наукового аналізу, систематизації, класифікації, моделювання. Сукупність застосованих методів забезпечує екстраполяцію загальних основ системології на практичні проблеми професійної підготовки сучасного філолога в умовах університету.

\section{Результати та їх обговорення}

Системний підхід до проблеми професійної підготовки філологів потребує детального вивчення концепта «система» в його методологічному значенні, що, в свою чергу, звертає нас до системології як науки про системні об єкти, явища $\mathrm{i}$ процеси. Як свідчать грунтовні дослідження I. Блауберга, Е. Юдіна (Блауберг\&Юдін, 1973), А. Кононюка (Кононюк, 2014), система є загальнометодологічною категорією філософського змісту, що реалізується нині як міждисциплінарне поняття у різних сферах людського знання. Наше дослідження спирається на дві взаємопов язані системологічні галузі - педагогічну (що визначає педагогічний зміст систем різного типу, виду і наповнення) та лінгвістичну системологію (що окреслює мову як складну динамічну систему знаків, що має метахарактер відносно інших знакових систем у професійній підготовці філологів), які забезпечують міжгалузевий характер використання системного підходу до професійної підготовки майбутніх філологів в університеті. При цьому педагогічна системологія виступає методологічним інструментом формування основних моделей і технологій професійної підготовки філолога, натомість лінгвістична - забезпечує 
знакове (семіотичне i смислове) наповнення змісту професійної підготовки названих фахівців.

Як свідчить загальна теорія систем (Ю. Бех, А. Слєпцов (Бех\&Слєпцов, 2012); Н. Чорней, Р. Чорней (Чорней\&Чорней, 2005), дослідження системних об єктів передбачає, передовсім, виявлення їх сутності, складу, структури, функцій та історії; крім цього, важливе значення має аналіз відносин системного об єкта із зовнішнім середовищем та обгрунтування основних чинників, що забезпечують цілісний розвиток системи. 3 позицій педагогічної системології професійна підготовка філологів в умовах університету як системний об єкт може бути представлена як у таблиці 1.

Як свідчать дослідження А. Кононюка (Кононюк, 2014:22), для постпостмодерного етапу розвитку науки традиційним є розгляд систем як синергетичних об єктів. У цьому відношенні професійна підготовка майбутніх філологів є складною і здатною до самоорганізації системою, що має відповідні дисипативні підструктури, які визначають можливості іiі розвитку на макро- та мікрорівнях - залежно від загальних трансформаційих процесів у вищій школі, 3 одного боку, та індивідуально-особистісних змін кожного суб єкта освітнього процесу - 3 іншого. Підготовка філолога в університеті тлумачиться нами як нелінійний відкритий процес, оскільки на нього впливає сукупність зовнішніх (загальні культурні і комунікативні процеси у світі, глобалізація мовного простору та ін.) і внутрішніх (специфіка освітнього середовища університету, особливості розробки й реалізації змісту, форм і методів професійної підготовки філологів) чинників. 


\section{Дослідження основних системних характеристик професійної підготовки філологів в університеті}

\begin{tabular}{|c|c|c|}
\hline $\begin{array}{c}\text { Системна } \\
\text { характеристика }\end{array}$ & $\begin{array}{c}\text { Ï̈̈ основний } \\
\text { зміст }\end{array}$ & $\begin{array}{l}\text { Прояви системної характеристики в } \\
\text { професійній підготовці філологів в } \\
\text { університеті як системному об єкті }\end{array}$ \\
\hline $\begin{array}{l}\text { Сутність } \\
\text { системи }\end{array}$ & $\begin{array}{l}\text { Ця } \\
\text { характеристика } \\
\text { визначає } \\
\text { основні } \\
\text { інтегративні } \\
\text { властивості } \\
\text { системи }\end{array}$ & 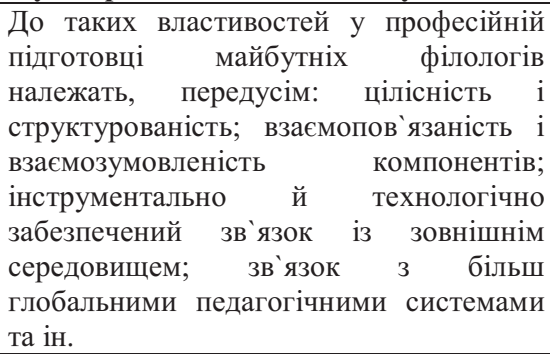 \\
\hline Склад системи & $\begin{array}{l}\text { Означена } \\
\text { системна } \\
\text { характеристика } \\
\text { визначає } \\
\text { кількісні та } \\
\text { якісні параметри } \\
\text { системи }\end{array}$ & 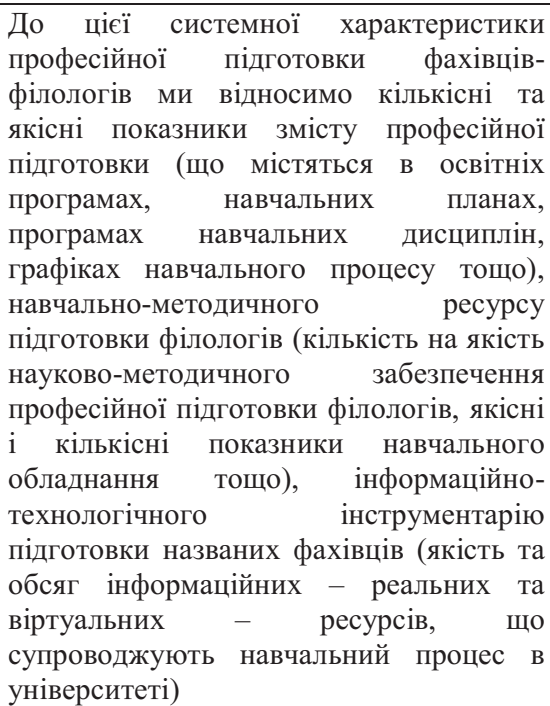 \\
\hline $\begin{array}{l}\text { Структура } \\
\text { системи }\end{array}$ & $\begin{array}{l}\text { Ця } \\
\text { характеристика } \\
\text { відображає } \\
\text { специфіку } \\
\text { внутрішньої } \\
\text { організації } \\
\text { системного } \\
\text { об`єкта }\end{array}$ & $\begin{array}{lrr}\text { Внутрішня } & \text { організація } & \text { процесу } \\
\text { професійної } & \text { підготовки } \\
\text { файбутніх } \\
\text { сілологів забезпечується взаємозв язком } \\
\text { структурних компонентів цього процесу: } \\
\text { цільового, методологічного, змістового, } \\
\text { процесуального й оцінного, що в сумі } \\
\text { складають науково-методичну систему } \\
\text { професійної підготовки філологів в } \\
\text { університеті }\end{array}$ \\
\hline
\end{tabular}




\section{продовження Таблиці 1}

\begin{tabular}{|c|c|c|}
\hline Функції системи & $\begin{array}{l}\text { Серед } \\
\text { найважливіших } \\
\text { функцій системи } \\
\text { можемо } \\
\text { виділити } \\
\text { адаптивну, } \\
\text { інформаційну, } \\
\text { розвивальну, } \\
\text { інструментальну }\end{array}$ & 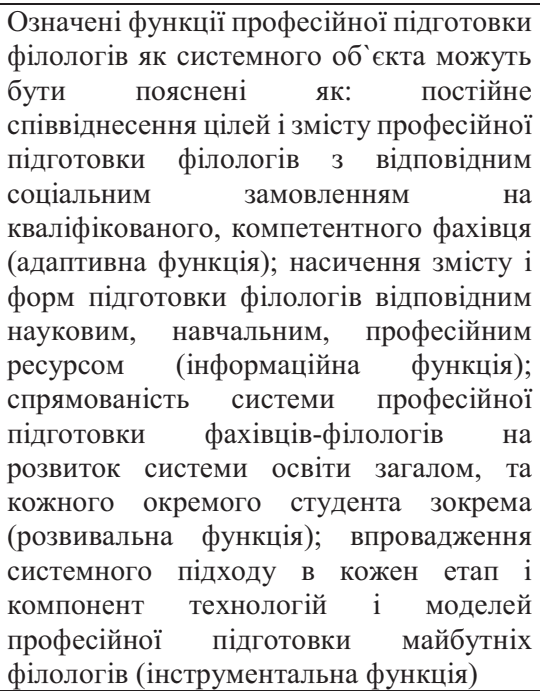 \\
\hline Історія системи & $\begin{array}{l}\text { Ця системна } \\
\text { характеристика } \\
\text { визначає } \\
\text { джерела } \\
\text { виникнення та } \\
\text { першопочатки } \\
\text { кожної } \\
\text { досліджуваної } \\
\text { системи, процес } \\
\text { їі становлення та } \\
\text { провідні } \\
\text { тенденції }\end{array}$ & 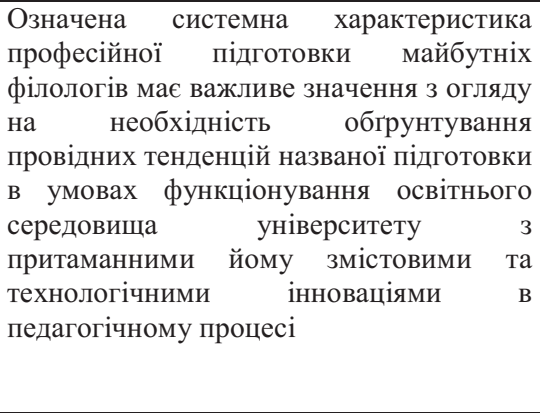 \\
\hline
\end{tabular}

\section{[Джерело: розроблено автором]}

Системологія дає можливість виокремити провідні види систем, беручи до уваги різні критерії означеного поділу: матеріальні й абстрактні системи (за їх призначенням); відкриті і закриті (за специфікою взаємодії iз середовищем та іншими системами); динамічні і статичні (за станом розвитку); прості, великі і складні (за рівнем складності); цілеспрямовані і нецільові (за наявними цілями); дифузні, складноорганізовані і самоорганізовані (за 
рівнем організації). При цьому професійна підготовка філологів в університеті як системний об`єкт може бути схарактеризована нами як складна відкрита динамічна цілеспрямована система 3 характеристиками постійної самоорганізації (рис.1.).

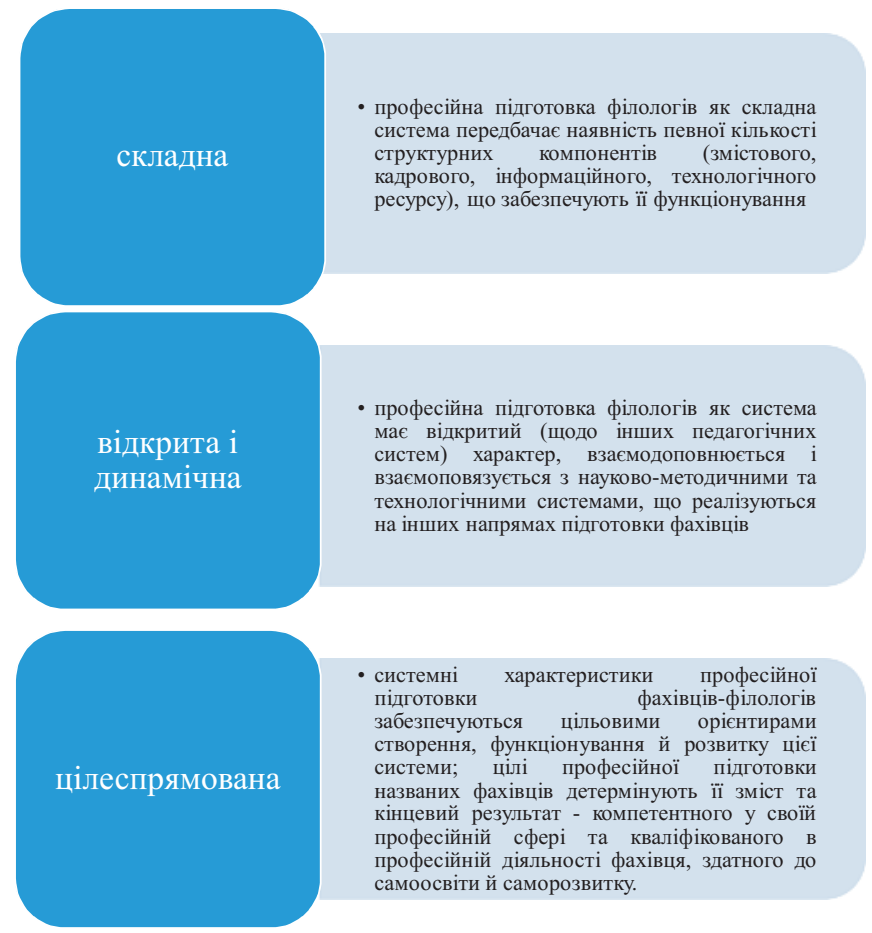

Рис.1. Професійна підготовка майбутніх філологів в університеті як складна відкрита динамічна система.

\section{Висновки}

Таким чином, нами схарактеризовано особливості застосування системного підходу до професійної підготовки майбутніх філологів в університетах. На підставі аналізу наукових джерел (методологічних засад професійної підготовки філологів; змісту та основних моделей підготовки 
названих фахівців; ІКТ як системного ресурсу підготовки фахівців-філологів) обгрунтовано думку про необхідність застосування педагогічної системології до професійної підготовки студентів-філологів в умовах університету. Аналіз педагогічного та лінгвістичного сегментів системології уможливив виокремлення провідних системних характеристик професійної підготовки філологів в університеті (сутність, склад, структура, функції, історія системи) та з'ясування прояву системних характеристик досліджуваного явища в умовах університетського середовища як системного об єкта. Сформульовано висновок про синергетичний характер професійної підготовки майбутніх філологів в університеті як системи; професійна підготовка філологів в університеті як системний об єкт схарактеризована як складна відкрита динамічна цілеспрямована система 3 характеристиками постійної самоорганізації.

\section{Література}

1. Барбаш I. Формування професійної мовно-літературної компетентності майбутніх учителів-філологів як педагогічна проблема. Проблеми підготовки сучасного вчителя. 2014. № 10 (Ч1). С. 152-157.

2. Бахтин М.М. Проблемь текста в лингвистике, филологии и других гуманитарных науках. Onыт философского анализа. Русская словесность. От теории словесности к структуре текста: Антология. Москва: Academia, 1997. С. 227-245.

3. Бех Ю.В., Слєпцов А.І. Філософські проблеми сучасного управління складними системами : ідеї, принциипи $i$ моделі : монографія. Київ: Вид-во НПУ імені М.П. Драгоманова, 2012. 404 с. URL: http://enpuir.npu.edu.ua/handle/123456789/5980.

4. Бігич О.Б. Методична освіта майбутнього вчителя іноземної мови початкової иколи: монографія. Київ: КНЛУ, 2004. 287 c. 
5. Блауберг И.В., Юдин Э.Г. Становление и сущзность системного подхода: монография. Москва: «Наука», 1973. 246 c.

6. Вознюк О.В., Дубасенюк О.А. Цільові орієнтири розвитку особистості у системі освіти: інтегративний niдxiд: монографія. Житомир: ЖДУ ім І. Франка, 2009. 684 с ISBN 978-966-485-054-1.

7. Зінукова Н.В. Професійно-методична підготовка студентів-філологів у вищому навчальному закладі: монографія. Дніпро: ДУЕП, 2009. 494 с.

8. Іконнікова М. Методологічні орієнтири професійної підготовки філологів. Педагогічний дискурс. 2016. Випуск 21. C.46-52.

9. Коваль В.О. Теоретичні і методичні засади формування професійної компетентності майбутніх учителів-філологів у вищих педагогічних навчальних закладах : монографія. Умань : ПП Жовтий О. О., 2013. 455 с.

10. Кононюк А.Е. Системология. Общуая теория систем: монографія. Київ: Освіта України, 2014. 564 с.

11. Семеног О.М. Професійна підготовка майбутніх учителів украӥнської мови і літератури: монографія. Суми : ВВП «Мрія-1» ТОВ, 2005. 404 с.

12. Чорней Н.Б., Чорней Р.К. Теорія систем і системний аналіз: навчальний посібник. Київ: МАУП, 2005. 256 с. ISBN 966-608-486-4.

13. Cummings J., Janicki T. N What Skills Do Students Need? A Multi-Year Study of IT/IS Knowledge and Skills in Demand by Employers. Journal of Information Systems Education. USA. 2020. №31(3). P. 208-217.

14. Gajewska E., Sowa M. Sposoby kształcenia nauczycieli języków specjalistycznych: od rzeczywistości edukacyjnej do rozwiązań systemowych. Neofilolog. 2015. № 44/2. S. 233-248.

15. Krajka J. The Language Teacher in the Digital Age. Towards a Systematic Approach to Digital Teacher Development. Lublin: KUL. 2012. P.18-38. 
16. Scialdone M.J., Connolly A.J. Teaching Tip: How to Teach Information Systems Students to Design Better User Interfaces through Paper Prototyping. Journal of Information Systems Education. 2020. №31(3). P.179-186.

17. Yong J.A. Teaching Tip. The Development of a Red Teaming Service-Learning Course. Journal of Information Systems Education (JISE). . 2020. Vol.31. Is.3. P.157-178.

\section{Боса В.П.}

\section{Професійна підготовка філологів в університеті в світлі системного підходу}

\section{Анотація}

У статті схарактеризовано особливості застосування системного підходу до професійної підготовки майбутніх філологів в університетах. Встановлено основні чинники, що визначають необхідність застосування системного підходу до означеної проблеми. Аналіз педагогічного та лінгвістичного сегментів системології уможливив виокремлення провідних системних характеристик професійної підготовки філологів в університеті (сутність, склад, структура, функції, історія системи) та з`ясування прояву системних характеристик досліджуваного явища в умовах університетського середовища як системного об єкта. Професійна підготовка філологів в університеті як системний об єкт схарактеризована як складна відкрита динамічна цілеспрямована система 3 характеристиками постійної самоорганізації.

Ключові слова: педагогічна системологія, лінгвістика, компетентність, синергетика. 


\section{Боса B.П.}

\section{Профессиональная подготовка филологов в университете в свете системного подхода}

\section{Аннотация}

В статье охарактеризованы особенности применения системного подхода к профессиональной подготовке будущих филологов в университете. Установлены факторы, определяющие необходимость применения системного анализа процесса профессиональной подготовки будущих филологов (внешние и внутренние). Анализ педагогического и лингвистического сегментов системологии позволил выделить системные характеристики подготовки филологов (сущность, состав, структура, функции, история системы) и определить уровень проявления этих характеристик в условиях ресурсной среды университета как системного объекта. Обосновано связь педагогической системологии и педагогической синергетики в контексте профессиональной подготовки филологов; названная подготовка представлена в исследовании как сложная открытая целенаправленная динамическая система с характеристиками постоянной самоорганизации.

Ключевые слова: педагогическая системология, лингвистика, компетентность, синергетика. 